\title{
Perindoprilat Changes ANG (1-9) Production in Renal Arteries Isolated From Young Spontaneously Hypertensive Rats After ANG I Incubation
}

\section{P. P. WOLKOW ${ }^{1,2}$, B. BUJAK-GIŻYCKA ${ }^{1,2}$, J. JAWIEN' $^{1}$, R. OLSZANECKI ${ }^{1}$, J. MADEJ $^{1}$, J. RUTOWSKI ${ }^{3}$, R. KORBUT ${ }^{1}$}

${ }^{1}$ Chair of Pharmacology, Jagiellonian University Medical College, Krakow, Poland, ${ }^{2}$ Center for Medical Genomics OMICRON, Jagiellonian University Medical College, Krakow, Poland, ${ }^{3}$ Department of Pharmacology, Medical Faculty, University of Rzeszów, Poland

Received February 13, 2015

Accepted October 16, 2015

On-line March 15, 2016

\begin{abstract}
Summary
We used mass spectrometry to quantitate production of angiotensinogen metabolites in renal artery of 3- and 7-monthold Wistar-Kyoto (WKY) and Spontaneously Hypertensive Rats (SHR). Tissue fragments were incubated for $15 \mathrm{~min}$ in oxygenated buffer, with added angiotensin I. Concentrations of angiotensins I (ANG I), II (ANG II), III (ANG III), IV (ANG IV), angiotensin (1-9) [ANG (1-9)], angiotensin (1-7) [ANG (1-7)], and angiotensin (1-5) [ANG (1-5)], excreted into the buffer during experiment, were measured using liquid chromatographymass spectrometry (LC/MS) and expressed per mg of dry tissue. Effects of pretreatment with $10 \mu \mathrm{M}$ perindoprilat on the production of ANG I metabolites were quantitated. Background production of any of ANG I metabolites differed neither between WKY and SHR rats nor between 3- and 7-month-old rats. Perindoprilat pretreatment of renal arteries resulted, as expected, in decrease of ANG II production. However, renal arteries of 7-month-old SHR rats were resistant to ACE inhibitor and did not change ANG II production in response to perindoprilat. In renal arteries, taken from 3-month-old rats, pretreated with perindoprilat, incubation with ANG I, resulted in the level of ANG (1-9) significantly higher in SHR than WKY rats. Our conclusion is that in SHR rats, sensitivity of renal artery ACE to perindoprilat inhibition changes with age.
\end{abstract}

\section{Key words}

Angiotensin (1-9) • Renal artery • Spontaneously hypertensive rat

\section{Corresponding author}

P. P. Wolkow, Department of Pharmacology, Jagiellonian University Medical College, 16 Grzegorzecka Str., Kraków 31-531, Poland. Fax: +48 1242172 17. E-mail: Pawel.Wolkow@uj.edu.pl

\section{Introduction}

Angiotensinogen metabolites play a prominent role in vasculature. For the long time, the most extensively studied pathway of metabolism of angiotensin I (ANG I) was formation of angiotensin II (ANG II), III (ANG III), and IV (ANG IV) through action of angiotensin converting enzyme (ACE) and aminopeptidases. Recently, cleavage of amino acids at the carboxy terminus of ANG I molecule, which leads to formation of angiotensins (1-9) (ANG (1-9)), (1-7) (ANG (1-7)), and (1-5) (ANG (1-5)) became also a subject of intense research (Vickers et al. 2002, Ferreira et al. 2012, Santos et al. 2013). Cleavage of carboxy terminal amino acid from ANG I to form ANG (1-9), mediated by angiotensin converting enzyme 2 (ACE 2), was discovered in the year 2000 (Donoghue et al. 2000, Tipnis et al. 2000). Other reactions in this pathway are mediated by cathepsins and neutral endopeptidases (Uehara et al. 2013, Jackman et al. 2002). Interest in this alternative pathway of ANG I metabolism is substantiated by the vasodilatatory and antiproliferative, i.e., cardioprotective effects of ANG (1-7), which are contrasted with vasoconstrictive and proliferative effects 
of ANG II (Chappell 2007, Iyer et al. 1998). Overproduction of ANG II plays an important role in development of hypertension and inhibitors of ACE are the cornerstone of antihypertensive therapy (Luque et al. 1996, Ferrario et al. 2005, Ferrario 2010). However, no drugs, targeting carboxy terminus cleaved angiotensins were developed for clinical use, so far.

Local renal RAS plays an important role in the development of kidney failure in hypertension (Obata et al. 2000, Ma et al. 2014, Zhuo et al. 2013) or in diabetic nephropathy (Soler et al. 2008, Ribeiro-Oliveira et al. 2008). Treatment with inhibitors of angiotensin converting enzyme (ACE-I) or with blockers of ANG II receptor $\left(\mathrm{AT}_{1}\right)$ is still a cornerstone of therapy in patients with hypertension and diabetic kidney diseases (Ferreira et al. 2012, Luque et al. 1996, Ferrario et al. 2005).

Tikellis et al. (2006) described developmental changes in ACE and ACE2 expression and activity in spontaneously hypertensive rats (SHR) and Wistar-Kyoto (WKY) controls. Interestingly, ACE but not ACE2 activity was lower in SHR rats compared to WKY controls. The aim of our study was to determine whether sensitivity of renal arteries to ACE inhibition changes with age and how this impacts ANG I metabolism in SHR and WKY rats.

Inbred strain of SHR rat is a well-established model of genetically determined hypertension. We incubated in water bath fragments of renal artery, isolated from SHR and WKY rats at the age of 3 months (when hypertension reaches plateau, Tikellis et al. 2006) and at 7 months (before the onset of kidney damage, Braun et al. 2013) to quantitate, by LC/MS method, production of ANG I metabolites. The effects of perindoprilat (an ACE-I) on angiotensin metabolism were also studied.

\section{Materials and Methods}

Animals

Male WKY and SHR rats, 3-month-old ( $\mathrm{n}=9$ for each strain), 330-400 $\mathrm{g}$ and 310-360 $\mathrm{g}$ of weight, respectively and 7 -month-old ( $\mathrm{n}=10$ for each strain), $340-410 \mathrm{~g}$ and 400-440 $\mathrm{g}$ of weight, respectively, were administered fraxiparine (2850 IU, i.p.) and anesthetized with $50 \mathrm{mg}$ of thiopentone $(50 \mathrm{mg} / \mathrm{ml}$, i.p.). Fragments of renal artery were excised through abdominal incision. All experimental studies using animals were approved by an Ethical Committee at the Jagiellonian University (No 12/2006).
Preparation of tissue fragments and "organ-bath" procedure

Tissue fragments were washed with cold, standard Krebs-Henseleit solution and cleaned of thrombi and tissue remnants. Blood vessels were cut into a suitable number of rings and rectangular rosettes of about $2 \mathrm{~mm}^{2}$ each. Tissue incubation was performed as described previously (Bujak-Giżycka et al. 2007) in our earlier established and optimized protocol. Briefly, tissue fragments were incubated in triplicates, each in $400 \mu \mathrm{l}$ of freshly prepared, $95 \%$ oxygen and $5 \% \mathrm{CO}_{2}$ bubbled Krebs buffer (at $37^{\circ} \mathrm{C}$ ) with or without an ACE-I perindoprilat at final concentration of $10 \mu \mathrm{M}$. Before addition of any exogenous substance, sample of $50 \mu \mathrm{l}$ of buffer was removed to provide information on background levels of ANG I metabolites. After 5 min of incubation with perindoprilat or buffer, ANG I was added to a final concentration of $1 \mu \mathrm{M}$ and samples were incubated for further $15 \mathrm{~min}$ (the choice of incubation times and substance concentrations was based on pilot experiments to provide the broadest possible representation of ANG I metabolite spectrum). Then, incubation buffer was removed and analyzed by LC/MS. Tissue fragments were dried overnight at $60^{\circ} \mathrm{C}$ and weighed to allow estimation of peptides' production per mg of dry tissue.

\section{Chemicals}

ANG II and ANG (1-7) were purchased from Sigma Chemicals (USA). Angiotensins: ANG I, ANG III, ANG IV and ANG (1-9) as well as ANG (1-5) were purchased from Bachem (USA). Perindoprilat was a gift from Servier (France). Formic acid (99\%), trifluoroacetic acid (TFA) and ammonium formate were purchased from Fluka (USA). Acetonitrile (J. T. Baker, USA), and water (Rathburn, Scotland) were HPLC grade.

\section{LC/MS measurement of angiotensin peptides}

Metabolites of ANG I were analyzed by LC/MS method, developed in our previous studies (BujakGiżycka et al. 2007, Olszanecki et al. 2008), with analytical conditions optimized to current type of samples. Separation of peptides was performed on a reversed-phase HPLC system, equipped with a quaternary high pressure pump L-7000 (Merck, Germany), using a Purospher STAR RP C18e column $(125 \mathrm{~mm} \times 2 \mathrm{~mm} \mathrm{ID,} 5 \mu \mathrm{m}$ particle size) with an appropriate guard C18 column $(4 \mathrm{~mm} \times 4 \mathrm{~mm}$ ID, $5 \mu \mathrm{m}$ particle size). Samples were injected onto chromatographic column in a volume of $50 \mu \mathrm{l}$. The 


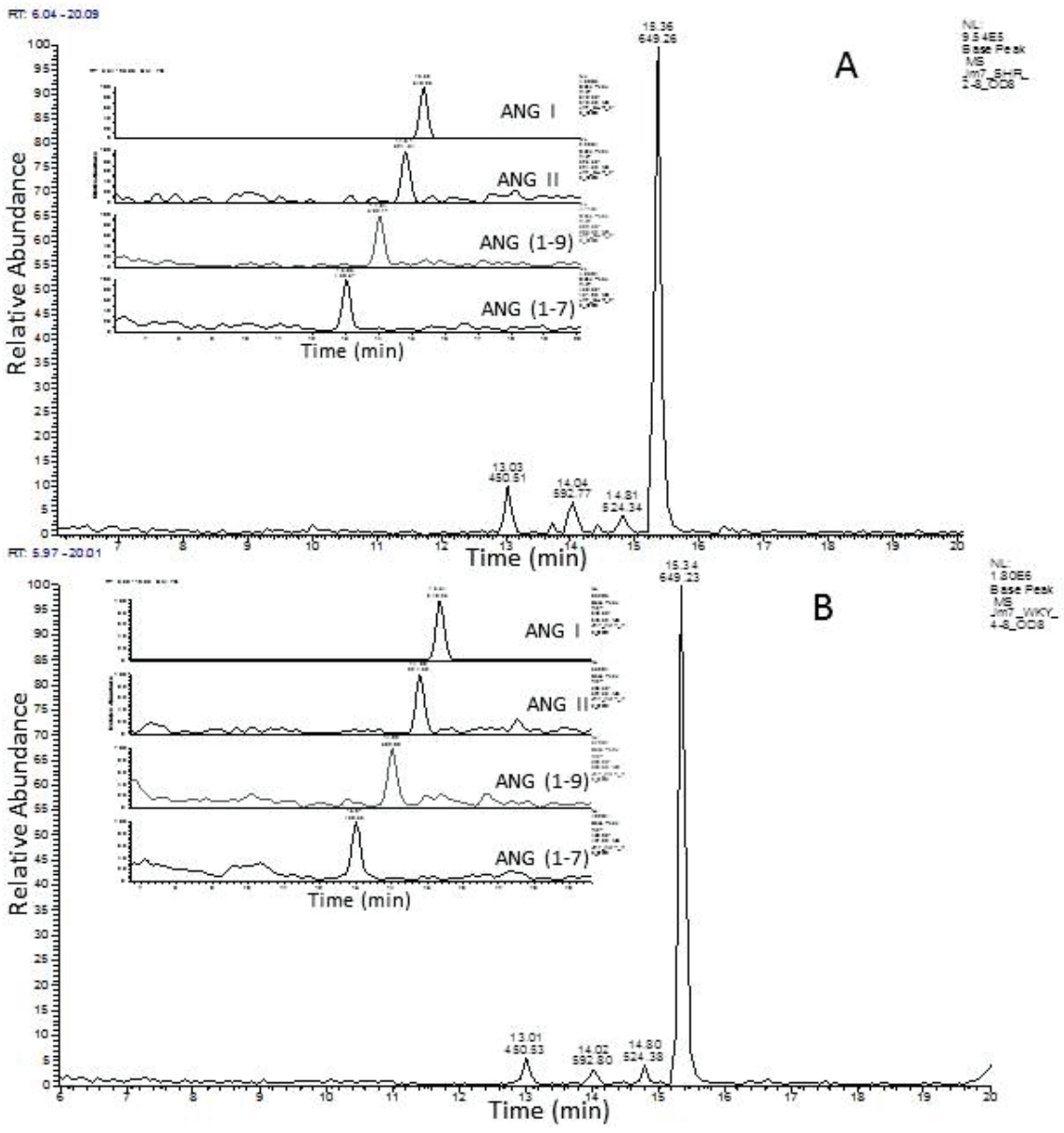

Fig. 1. Representative chromatograms of products of ANG I conversion by renal artery of SHR (A) and WKY (B) rats. Inserts show extracted values of monitored ions of major metabolites.

optimized mobile phase solvents were: $5 \%$ acetonitrile in a buffer of $4 \mathrm{mM}$ ammonium formate with $4 \mathrm{mM}$ of formic acid (phase A) and 90\% acetonitrile in the same buffer (phase B). Angiotensin peptides were separated at a flow rate of $0.25 \mathrm{ml} / \mathrm{min}$ with a linear gradient of $\mathrm{B}$ in A. Retention times were as follow: $13.00 \mathrm{~min}$ (ANG (1-7)), $13.70 \mathrm{~min}$ (ANG (1-5)), $14.00 \mathrm{~min}$ (ANG (1-9)), $14.45 \mathrm{~min}$ (ANG III), $14.80 \mathrm{~min}$ (ANG II), $15.10 \mathrm{~min}$ (ANG IV) and $15.35 \mathrm{~min}$ (ANG I).

Mass spectrometric detection was performed using an LCQ ion-trap mass spectrometer (Finnigan, San Jose, USA), with an ESI source (electrospray). All experiments were carried out in the positive ion mode (ion spray voltage $5 \mathrm{kV}$; capillary voltage $46 \mathrm{~V}$; capillary temperature $200{ }^{\circ} \mathrm{C}$, nitrogen flow rate $65 \mathrm{psi}$ ) and selective ion monitoring (SIM) mode, as previously described (Bujak-Giżycka et al. 2007). $\mathrm{M} / \mathrm{z}$ values of monitored ions corresponded mainly to doublyprotonated molecules of all angiotensins, except the single-charged ions of ANG IV and ANG (1-5), and were the following: 450 for ANG (1-7) (MW=899.02), 466 for ANG III (MW=931.11), 524 for ANG II (MW=1046.19), 592 for ANG (1-9) $(\mathrm{MW}=1183.34), 649$ for ANG I $(\mathrm{MW}=1296.51), 665$ for $\mathrm{ANG}(1-5)(\mathrm{MW}=664.76)$ and
775 for ANG IV (MW=774.92). Acquired data were analyzed by Xcalibur Software v. 1.2 (Fig. 1).

Samples for calibration curves of each examined peptide (mixture of standards) were analyzed in the same mode as above. Concentrations of angiotensins were calculated using the standard calibration curves, constructed by linear regression analysis by plotting of peak area vs. angiotensin concentration. Calibration curves were prepared for each examined peptide at a concentration range of $20 \mathrm{pM}-100 \mathrm{nM}$.

\section{Statistics}

Concentrations of angiotensins were expressed as in $\mathrm{pmol} / \mathrm{mg}$ dry tissue. All values in the figures and text are expressed as mean $\pm \mathrm{SD}$. Concentrations of studied analytes were compared using non-parametric Wilcoxon's test. A $P$ value of less than 0.05 was considered statistically significant.

\section{Results}

Background level of all of examined angiotensinogen metabolites was negligible and didn't influence the results of further conversion of exogenously 

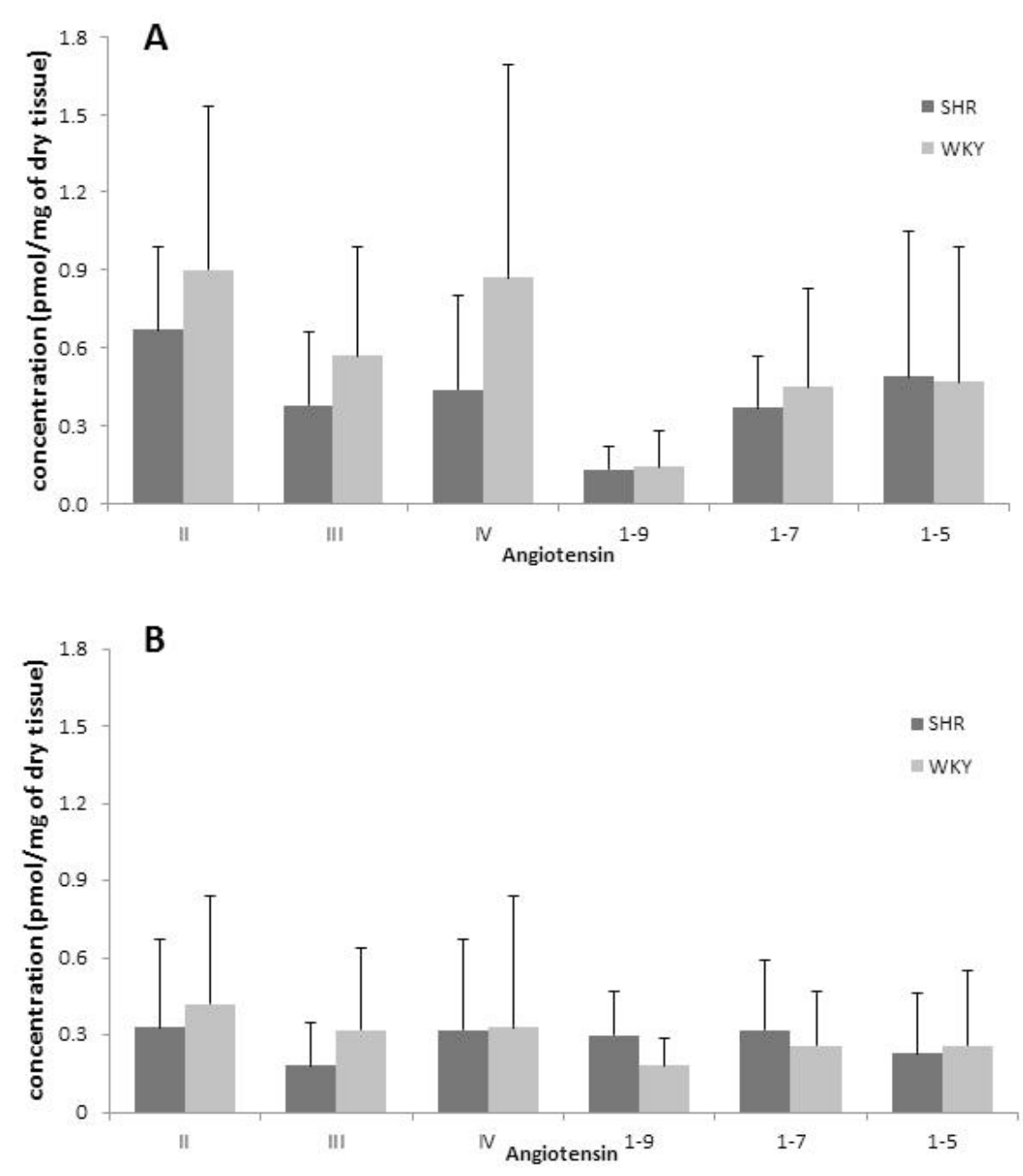

Fig. 2. Production of ANG I metabolites (pmol/mg of dry tissue, mean $\pm \mathrm{SD}$ ) in response to 15 min incubation of renal artery fragments from WKY and SHR rats with angiotensin I $(1 \mu \mathrm{M})$. A 3-month-old rats, B - 7-month-old rats. added ANG I.

After incubation of the renal arteries with ANG I, concentrations of produced metabolites [ANG II to ANG (1-5)] did not differ significantly between the rat strains, but were higher in 3-month-old than in 7-monthold animals $(\mathrm{p}<0.04)$ for ANG II, ANG III, and ANG IV metabolites), and higher in 7-month-old rats for ANG (1-9) (Fig. 2 A-B).

The pattern of produced metabolites did not differ significantly between 7-month-old and 3-month-old rats, as well as between SHR and WKY strains. The main product of ANG I metabolism was ANG II, in all groups, but surprisingly, the higher production was observed in a control (WKY) group.

Pretreatment with perindoprilat caused very strong inhibition of ANG II production in WKY in comparison to SHR rats. In 3-month-old animals, effect of ACE-I action was significantly more pronounced than in 7-month-old rats. Concentration of ANG II was $88.88 \%$ lower in 3 -month-old WKY rats $(0.10 \mathrm{pmol} / \mathrm{mg}$ after perindoprilat pretreatment vs. $0.90 \mathrm{pmol} / \mathrm{mg})$, but in 7-month-old animals decrease was only $60.27 \%$ ( $0.17 \mathrm{pmol} / \mathrm{mg}$ vs. $0.42 \mathrm{pmol} / \mathrm{mg}$ ). Renal arteries of SHR rats were less sensitive to ACE-I action - in 3-month-old group $56.83 \%$ decrease was observed $(0.29 \mathrm{pmol} / \mathrm{mg}$ vs. $0.67 \mathrm{pmol} / \mathrm{mg}$ ), and surprisingly, only $8.73 \%$ inhibition in 7 -month-old rats $(0.30 \mathrm{pmol} / \mathrm{mg}$ vs. $0.33 \mathrm{pmol} / \mathrm{mg})$ (Fig. 3).

However, the most striking results obtained by us, concerned the level of ANG (1-9), produced by renal arteries after incubation with ANG I.

In 3-month-old rats (Fig. 4A), renal artery incubated with ANG I produced a similar amount of ANG (1-9) in both WKY and SHR rats. However, perindoprilat pretreatment of renal arteries, before ANG I incubation, almost tripled production of ANG (1-9) in SHR rats, while no increase or even some decline of ANG (1-9) production was evident in WKY rats $(\mathrm{p}<0.05$ comparing strains of 3-month-old rats pretreated with perindoprilat).

In 7-month-old SHR rats (Fig. 4B), production of ANG (1-9) after incubation of renal arteries with 


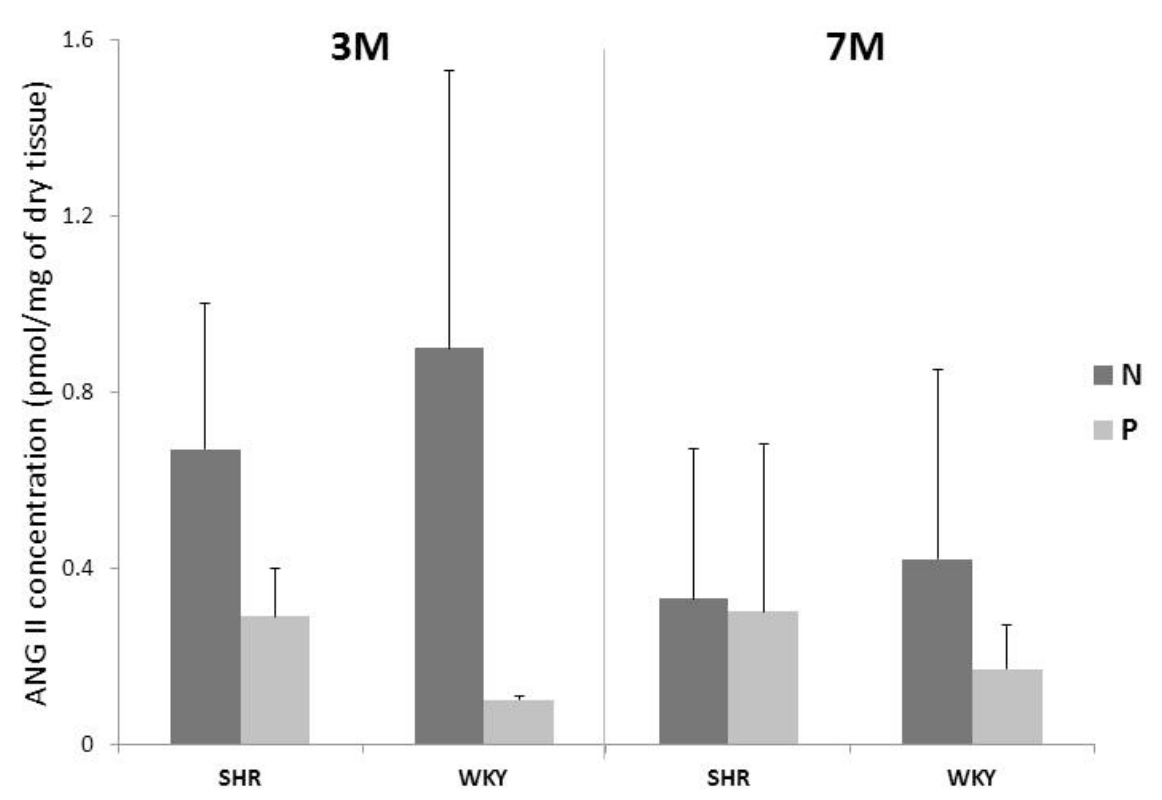

Fig. 3. Decrease of ANG II ( $\mathrm{pmol} / \mathrm{mg}$ of dry tissue, mean $\pm \mathrm{SD}$ ) production in renal arteries incubated with ANG I $(1 \mu \mathrm{M})$ and pretreated $(\mathrm{P})$ or not $(\mathrm{N})$ with perindoprilat $(10 \mu \mathrm{M})$ in 3-month-old (3M) and 7-month-old (7M) WKY and SHR rats.

ANG I is increased, compared to 3-month-old SHR rats. In 7-month-old SHR rats, the concentration of ANG (1-9) is similar to the level observed in 3-month-old rats pretreated with perindoprilat. In 7-month-old SHR rats, pretreatment with perindoprilat does not induce further increase in ANG (1-9) production.

In contrast to SHR rats, renal arteries of 7-month-old WKY rats produce from ANG I the similar amount of ANG (1-9) as 3-month-old WKY rats (Fig. 4B). However, perindoprilat pretreatment in this group of 7-month-old WKY rats leads to increase of ANG (1-9) production to the same level as in SHR rats. The influence of perindoprilat on production of ANG II, ANG (1-7) and ANG (1-9) in both strains of 3-month-old and 7-month-old rats is summarized in Table 1.

\section{Discussion}

In our study we assessed the metabolism of ANG I in renal arteries of spontaneously hypertensive rats. Apart from the dominant in the literature, classical pathway of metabolism to ANG II, ANG III, and ANG IV, an interesting alternative in the form of ANG (1-9), ANG (1-7), and ANG (1-5) was discovered. ANG (1-7) is an active peptide of RAS. It counteracts vasoconstriction by releasing nitric oxide and prostacyclin (Fang et al. 2013). Moreover, it opposes ANG II mitogenic, arrhythmogenic and procoagulant activities (Trask and Ferrario 2007). Enhancing natriuresis and diuresis, it inhibits water and sodium retention caused by ANG II. Recently, it has been shown that vasodilatative and diuretic activities of ANG (1-7) are mediated via Mas, a G-protein coupled receptor (Santos et al. 2003). Furthermore, some activities of ANG (1-7) are blocked by $\mathrm{AT}_{1}$ and $\mathrm{AT}_{2}$ receptors antagonists (Clark et al. 2001). On the other hand, ANG (1-7) independently to Mas receptor, increases bradykinin activity and antagonizes hypertrophic action of ANG II (Su 2014).

Chronic activation of RAS is a major cause of chronic kidney diseases. Main components of RAS are present within the kidney (angiotensinogen, $\mathrm{AT}_{1} \mathrm{R}$, renin and ACE). There are many evidences of the important role of intrarenal ACE in inducing hypertension, even in the absence of systemic ACE (Gonzalez-Villalobos et al. 2013).

Our results showed that there are specific age related differences in metabolic pathways. In renal arteries of 3-month-old animals, higher amounts of ANG II, ANG III, and ANG IV were formed than in 7-month-old rats while ANG (1-9) was produced in lower level in these rats. Our most important finding is that angiotensin (1-9) is elevated in renal arteries isolated from 7-month-old SHRs after incubation with ANG I and also after treatment with perindoprilat.

Still very little is known about the role of ANG (1-9), other than being a precursor of ANG (1-7). Recent studies suggest that this peptide has beneficial effects in hypertension and organ damage, caused by ANG II. There are strong evidences that ANG (1-9) could reduce the hypertension and ameliorate cardiac and aortic wall hypertrophy and fibrosis in hypertensive rats (Ocaranza et al. 2014b). Treatment with ANG (1-9) resulted in decrease of circulating ANG II level and ACE activity. 

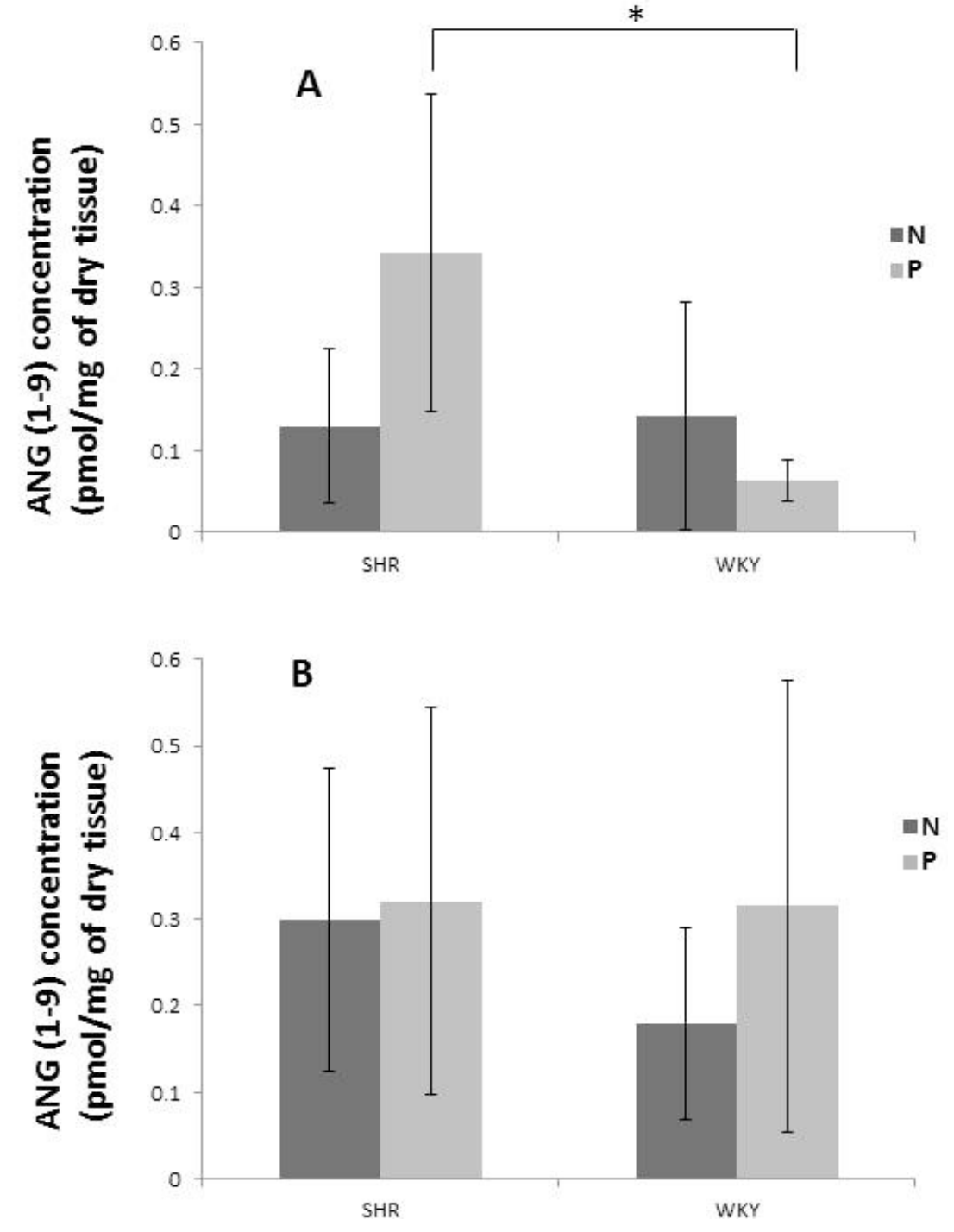

Fig. 4. Effect of perindoprilat $(10 \mu \mathrm{M})$ pretreatment $(\mathrm{P})$ or no pretreatment $(\mathrm{N})$ on ANG (1-9) concentration in ANG I (1 $\mu M)$ incubated renal arteries of 3-month-old (A) and 7-month-old (B) WKY and SHR rats $(\mathrm{pmol} / \mathrm{mg}$ of dry tissue, mean $\pm S D) . * p<0.05$
ANG (1-9) is the RAS peptide found in the plasma of healthy volunteers and in patients treated with ACE-I (McKinney et al. 2014). It was also demonstrated that the concentration of ANG (1-9) increases in plasma and heart tissue of rats after myocardial infarction (Ocaranza et al. 2006). It can be produced from ANG I by carboxypeptidase A (CPA) or a CPA-like enzyme (McKinney et al. 2014, Ocaranza et al. 2014a) or by the recently recognized ACE2 (Vickers et al. 2002, Donoghue et al. 2000, Tipnis et al. 2000). Campbell et al. (1991) found that ANG (1-9) concentration in the kidney homogenates was higher than concentration of ANG II. Concentration of ANG (1-9) reached there about $50 \%$ of ANG I level. Moreover, the main products of ANG I metabolism in human heart are both ANG (1-9) and ANG II, generated by heart chymase, ACE or carboxypeptidase A (Kokkonen et al. 1997). ANG (1-9) was shown to be a strong competitive inhibitor of ACE (at multiple-fold lesser concentration than ANG I) both in human heart and platelets (McKinney et al. 2014, Ocaranza et al. 2014a). Moreover, ANG (1-9), like ANG (1-7) and ACEIs, increases nitric oxide and arachidonic acid release due to enhanced bradykinin action on its $\mathrm{B}_{2}$ receptor (Jackman et al. 2002), while the links among vasodilator systems: NO, prostaglandins and bradykinin are already well known (Ocaranza et al. 2014a).

During the development of hypertension, changes in RAS components levels are observed. Results obtained from 5-week-old SHR rats (Zhou et al. 2012) showed that ANG II serum level increased rapidly for the first few weeks (starting from 5 to 11), then, up to 18 week, level of ANG II seems to achieve the steady state after the slight decrease. After $18^{\text {th }}$ week of age, ANG II level raised again. Interestingly, ANG (1-7) level showed the tendency to "plateau-like" until 14-week, then rapid increase was observed up to 17 week and next slight drop. Treatment with ACE-I resulted in significant decrease of ANG II production, but with low increase of 
Table 1. Concentrations of angiotensin II (ANG II), angiotensin (1-7) (ANG (1-7)) and angiotensin (1-9) (ANG (1-9)) [pmol/mg of dry tissue] after incubation of renal arteries of 3-month-old (3M) and 7-month-old (7M) Wistar-Kyoto (WKY) and Spontaneously Hypertensive (SHR) rats with $1 \mu \mathrm{M}$ angiotensin I (Mean \pm Standard Deviation, $\mathrm{pmol} / \mathrm{mg}$ of dry tissue).

\begin{tabular}{cccccccc}
\hline $\begin{array}{c}\text { Age } \\
\text { group }\end{array}$ & $\begin{array}{c}\text { Rat } \\
\text { strain }\end{array}$ & $\mathbf{N}$ & ANG II & \multicolumn{2}{c}{ ANG (1-7) } & \multicolumn{2}{c}{ ANG (1-9) } \\
\hline $3 M$ & $S H R$ & $0.67 \pm 0.33$ & $0.29 \pm 0.11$ & $0.37 \pm 0.20$ & $0.63 \pm 0.17$ & $0.13 \pm 0.09$ & $0.34 \pm 0.19$ \\
& $W K Y$ & $0.90 \pm 0.63$ & $0.10 \pm 0.01$ & $0.45 \pm 0.38$ & $0.43 \pm 0.26$ & $0.14 \pm 0.14$ & $0.06 \pm 0.02$ \\
$7 M$ & $S H R$ & $0.33 \pm 0.34$ & $0.30 \pm 0.38$ & $0.32 \pm 0.27$ & $0.27 \pm 0.26$ & $0.30 \pm 0.17$ & $0.32 \pm 0.22$ \\
& $W K Y$ & $0.42 \pm 0.43$ & $0.17 \pm 0.10$ & $0.26 \pm 0.21$ & $0.38 \pm 0.39$ & $0.18 \pm 0.11$ & $0.32 \pm 0.26$ \\
\hline
\end{tabular}

$\mathrm{P}$ - Renal arteries were pretreated with $10 \mu \mathrm{M}$ perindoprilat before addition of ANG I. N - no pretreatment with perindoprilat.

ANG (1-7). Nevertheless, these results concern circulating RAS and cannot be directly translated to production in the tissue.

There are only few studies of ANG I metabolism in renal artery. According to our previous results, metabolism of ANG I in renal artery differs from aorta (Bujak-Giżycka et al. 2007). In rat aorta, main metabolite of ANG I was also ANG II, but its production was significantly higher than other metabolites. This fact indicates the prominent role of ACE-dependent metabolic pathway, whereas in renal arteries other metabolites were in comparable levels as ANG II, possibly due to high activity of others RAS enzymes, like ACE2 or NEP.

In our experiments, pretreatment with perindoprilat resulted in decrease in ANG II production by renal arteries $(p=0.05)$. This effect was strongly pronounced in 3-month-old animals. Moreover, elevated production of ANG (1-7) and ANG (1-9) ( $\mathrm{p}=0.05)$ was observed in 3-month-old SHR rats, whereas in control group was negligible (Table 1).

Obtained results suggest that ACE-I caused not only expected decrease of ANG II formation, but also higher production of ANG (1-9) and more intensive metabolism of ANG II to ANG (1-7). Additionally, lower sensitivity of renal artery to ACE inhibition was observed in SHR rats at 7 months of age. Our data are in line with the results of Tikellis et al. (2006) who demonstrated that activity of ACE but not that of ACE2 is lower in 80-dayold SHR rats compared to WKY controls and with the results of Mooradian and Lieberman (1990) who observed lower activity of ACE in 6- compared to 2-month-old Fisher rats.

Quantitation of angiotensin peptides requires very specific and sensitive methods. In many studies, the most popular were radioimmunoassay (RIA) or ELISA measurements (Liu et al. 2011, Wang et al. 2003), but these methods do not allow to distinguish and assess each one of ANG I metabolites. This aim can be achieved by using liquid chromatography separation techniques (Singh et al. 2005), especially with mass spectrometric detection, like LC/MS (Olszanecki et al. 2008, Suski et al. 2013, Cui et al. 2007) or MALDI/TOF (Velez et al. 2009). We developed LC/MS method to measure angiotensin metabolism in ex vivo model (Fig. 1). This method was used in our studies, not only in animal tissue (Bujak-Giżycka et al. 2007, Olszanecki et al. 2008), but also in cell lines (Suski et al. 2013) and human tissue fragments (Stettner et al. 2013).

However, our study has got some limitations. $E x$ vivo model, used in present experiment, does not show the endogenous levels of ANG I peptides, but rather describes the "ability" of current tissue to metabolize ANG I. Similar models were successfully used by other authors (Velez et al. 2009, Singh et al. 2005) as well as in our earlier studies (Bujak-Giżycka et al. 2007, Olszanecki et al. 2008, Stettner et al. 2013) and we suppose that results are adequate to living tissue. On the other hand, it could be noticed that in this model, isolated tissue fragments present a static system, without influence of many biochemical pathways and without dynamic changes, characteristic for the living body.

In conclusion, we found that with ageing, renal artery of SHR rat become less sensitive to treatment with ACE-Is. Moreover, our observation that ANG (1-9) is elevated in renal arteries of 3-month-old rats after ANG I and perindoprilat incubation in SHRs corroborates with the previous observations, pointing towards the role of ACE2 - ANG (1-7) - receptor Mas axis as an important endogenous mechanism of homeostasis in young rats, despite strong pressure from the opposite ACE - ANG II $-\mathrm{AT}_{1}$ receptor axis (Chappell 2007). Confirmation of this mechanism could be obtained by experiments in "gene- 
targeted" mice without functional Mas receptor.

\section{Conflict of Interest}

There is no conflict of interest.

\section{Acknowledgements}

This article was supported by the grants from Polish
National Center of Science (NCN): No 2012/05/B/NZ4/02743, N N402 096 32/3258, N N402 468937, N N401 293939, and from statutory funds of the Jagiellonian University Medical College K/ZDS/001488. We would like to thank Servier company for a gift of perindoprilat. We also thank Jolanta Reyman and Alicja Starościak for their excellent technical support.

\section{References}

BRAUN MC, HERRING SM, GOKUL N, MONITA M, BELL R, HICKS MJ, WENDERFER SE, DORIS PA: Hypertensive renal disease: susceptibility and resistance in inbred hypertensive rat lines. J Hypertens 31: 20502059, 2013.

BUJAK-GIZYCKA B, MADEJ J, WOŁKOW PP, OLSZANECKI R, DRABIK L, RUTOWSKI J, KORBUT R: Measurement of angiotensin metabolites in organ bath and cell culture experiments by liquid chromatography - electrospray ionization - mass spectrometry (LC-ESI-MS). J Physiol Pharmacol 58: 529-540, 2007.

CAMPBELL DJ, LAWRENCE AC, TOWRIE A, KLADIS A, VALENTIJN AJ: Differential regulation of angiotensin peptide levels in plasma and kidney of the rat. Hypertension 18: 763-773, 1991.

CHAPPELL MC: Emerging evidence for a functional angiotensin-converting enzyme 2-angiotensin-(1-7)-MAS receptor axis: more than regulation of blood pressure? Hypertension 50: 596-599, 2007.

CLARK MA, DIZ DI, TALLANT EA: Angiotensin-(1-7) downregulates the angiotensin II type 1 receptor in vascular smooth muscle cells. Hypertension 37: 1141-1146, 2001.

CUI L, NITHIPATIKOM K, CAMPBELL WB: Simultaneous analysis of angiotensin peptides by LC-MS and LC-MS/MS: metabolism by bovine adrenal endothelial cells. Anal Biochem 369: 27-33, 2007.

DONOGHUE M, HSIEH F, BARONAS E, GODBOUT K, GOSSELIN M, STAGLIANO N, DONOVAN M, WOOLF B, ROBISON K, JEYASEELAN R, BREITBART RE, ACTON S: A novel angiotensin converting enzymerelated carboxypeptidase (ACE2) converts angiotensin I to angiotensin 1-9. Circ Res 87: E1-E9, 2000.

FANG C, STAVROU E, SCHMAIER AA, GROBE N, MORRIS M, CHEN A, NIEMAN MT, ADAMS GN, LARUSCH G, ZHOU Y, BILODEAU ML, MAHDI F, WARNOCK M, SCHMAIER AH: Angiotensin 1-7 and Mas decrease thrombosis in Bdkrb2-/- mice by increasing NO and prostacyclin to reduce platelet spreading and glycoprotein VI activation. Blood 121: 3023-3032, 2013.

FERRARIO CM: Addressing the theoretical and clinical advantages of combination therapy with inhibitors of the renin-angiotensin-aldosterone system: antihypertensive effects and benefits beyond BP control. Life Sci 86: 289-299, 2010.

FERRARIO CM, JESSUP J, CHAPPELL MC, AVERILL DB, BROSNIHAN KB, TALLANT EA, DIZ DI, GALLAGHER PE: Effect of angiotensin-converting enzyme inhibition and angiotensin II receptor blockers on cardiac angiotensin-converting enzyme 2. Circulation 111: 2605-2610, 2005.

FERREIRA AJ, MURÇA TM, FRAGA-SILVA RA, CASTRO CH, RAIZADA MK, SANTOS RA: New cardiovascular and pulmonary therapeutic strategies based on the Angiotensin-converting enzyme 2/angiotensin-(1-7)/mas receptor axis. Int J Hypertens 2012: 147825, 2012.

GONZALEZ-VILLALOBOS RA, JANJOULIA T, FLETCHER NK, GIANI JF, NGUYEN MTX, RIQIUER-BRISON AD, SETH DM, FUCHS S, ELADARI D, PICARD N, BACHMANN S, DELPIRE E, PETI-PETERDI J, NAVAR LG, BERNSTEIN KE, MCDONOUGH AA: The absence of intrarenal ACE protects against hypertension. J Clin Invest 123: 2011-2023, 2013.

IYER SN, FERRARIO CM, CHAPPELL MC: Angiotensin-(1-7) contributes to the antihypertensive effects of blockade of the renin-angiotensin system. Hypertension 31: 356-361, 1998.

JACKMAN HL, MASSAD MG, SEKOSAN M, TAN F, BROVKOVYCH V, MARCIC BM, ERDÖS EG: Angiotensin 1-9 and 1-7 release in human heart: role of cathepsin A. Hypertension 39: 976-981, 2002. 
KOKKONEN JO, SAARINEN J, KOVANEN PT: Regulation of local angiotensin II formation in the human heart in the presence of interstitial fluid. Inhibition of chymase by protease inhibitors of interstitial fluid and of angiotensin-converting enzyme by Ang-(1-9) formed by heart carboxypeptidase A like activity. Circulation 95 : 1455-1463, 1997.

LIU CX, HU Q, WANG Y, ZHANG W, MA ZY, FENG JB, WANG R, WANG XP, DONG B, GAO F, ZHANG MX, ZHANG Y: Angiotensin-converting enzyme (ACE) 2 overexpression ameliorates glomerular injury in a rat model of diabetic nephropathy: a comparison with ACE inhibition. Mol Med 17: 59-69, 2011.

LUQUE M, MARTIN P, MARTELL N, FERNANDEZ C, BROSNIHAN KB, FERRARIO CM: Effects of captopril related to increased levels of prostacyclin and angiotensin-(1-7) in essential hypertension. J Hypertens 14: 799-805, 1996.

MA C, XIN H, JIANG XY, WANG YX, ZHANG YS: Relationship between renal injury and the antagonistic roles of angiotensin-converting enzyme (ACE) and ACE2. Genet Mol Res 13: 2333-2342, 2014.

MCKINNEY CA, FATTAH C, LOUGHREY C, MILLIGAN G, NICKLIN SA: Angiotensin-(1-7) and angiotensin-(1-9): function in cardiac and vascular remodeling. Clin Sci (Lond) 126: 815-827, 2014.

MOORADIAN AD, LIEBERMAN J: Age-related decrease in serum angiotensin converting enzyme activity: the role of thyroidal status and food intake. J Gerontol 45: B24-B27, 1990.

OBATA J, NAKAMURA T, TAKANO H, NAITO A, KIMURA H, YOSHIDA Y, SHIMIZU F, GUO DF, INAGAMI T: Increased gene expression of components of the renin- angiotensin system in glomeruli of genetically hypertensive rats. J Hypertens 18: 1247-1255, 2000.

OCARANZA MP, GODOY I, JALIL JE, VARAS M, COLLANTES P, PINTO M, ROMAN M, RAMIREZ C, COPAJA M, DIAZ-ARAYA G, CASTRO P, LAVANDERO S: Enalapril attenuates downregulation of angiotensin-converting enzyme 2 in the late phase of ventricular dysfunction in myocardial infarcted rat. Hypertension 48: 572-578, 2006.

OCARANZA MP, MICHEA L, CHIONG M, LAGOS CF, LAVANDERO S, JALIL JE: Recent insights and therapeutic perspectives of angiotensin-(1-9) in the cardiovascular system. Clin Sci (Lond) 127: 549-557, 2014a.

OCARANZA MP, MOYA J, BARRIENTOS V, ALZAMORA R, HEVIA D, MORALES C, PINTO M, ESCUDERO N, GARCÍA L, NOVOA U, AYALA P, DÍAZ-ARAYA G, GODOY I, CHIONG M, LAVANDERO S, JALIL JE, MICHEA L: Angiotensin-(1-9) reverses experimental hypertension and cardiovascular damage by inhibition of the angiotensin converting enzyme/ Ang II axis. J Hypertens 32: 771-783, $2014 \mathrm{~b}$.

OHNISHI K, MURASE M, NAKANO D, PELISH N, HITOMI H, KOBORI H, MORIMOTO S, MORI H, MASAKI T, OHMORI K, KOHNO M, ICHIHARA A, NISHIYAMA A: Angiotensin-converting enzyme inhibitor does not suppress renal angiotensin II levels in angiotensin I-infused rats. J Pharmacol Sci 122: 103-108, 2013.

OLSZANECKI R, BUJAK-GIŻYCKA B, MADEJ J, SUSKI M, WOŁKOW PP, JAWIEŃ J, KORBUT R: Kaempferol, but not resveratrol inhibits angiotensin converting enzyme. J Physiol Pharmacol 59: 387-392, 2008.

RIBEIRO-OLIVEIRA A Jr, NOGUIERA AI, PEREIRA RM, BOAS WW, DOS SANTOS RA, SIMOES E SILVA AC: The renin-angiotensin system and diabetes: an update. Vasc Health Risk Manag 4: 787-803, 2008.

SANTOS RA, SIMOES E SILVA AC, MARIC C, SILVA DM, MACHADO RP, DE BUHR I, HERINGERWALTHER S, PINHEIRO SV, LOPES MT, BADER M, MENDES EP, LEMOS VS, CAMPAGNOLESANTOS MJ, SCHULTHEISS HP, SPETH R, WALTHER T: Angiotensin-(1-7) is an endogenous ligand for the G protein-coupled receptor Mas. Proc Natl Acad Sci USA 100: 8258-8263, 2003.

SANTOS RA, FERREIRA AJ, VERANO-BRAGA T, BADER M: Angiotensin-converting enzyme 2, angiotensin-(1-7) and Mas: new players of the renin-angiotensin system. $J$ Endocrinol 216: R1-R17, 2013.

SINGH R, SINGH AK, LEEHEY DJ: A novel mechanism for angiotensin II formation in streptozotocin-diabetic rat glomeruli. Am J Physiol Renal Physiol 288: F1183-F1190, 2005.

SOLER MJ, WYSOCKI J, BATTLE D: Angiotensin-converting enzyme 2 and the kidney. Exp Physiol 93: 549-556, 2008.

STETTNER D, BUJAK-GIŻYCKA B, OLSZANECKI R, RYTLEWSKI K, HURAS H, KORBUT R: Assessment of angiotensin I metabolism in the human placenta using an LC/MS method. Folia Med Cracov 53: 31-39, 2013. 
SU JB: Different cross-talk sites between the renin-angiotensin and the kallikrein-kinin systems. $J$ Renin Angiotensin Aldosterone Syst 15: 319-328, 2014.

SUSKI M, GĘBSKA A, OLSZANECKI R, STACHOWICZ A, URACZ D, MADEJ J, KORBUT R: Influence of atorvastatin on angiotensin I metabolism in resting and TNF- $\alpha$-activated rat vascular smooth muscle cells. J Renin Angiotensin Aldosterone Syst 15: 378-383, 2014.

TIKELLIS C, COOPER ME, BIALKOWSKI K, JOHNSTON CI, BURNS WC, LEW RA, SMITH AI, THOMAS MC: Developmental expression of ACE2 in the SHR kidney: a role in hypertension? Kidney Int 70: 34-41, 2006.

TIPNIS SR, HOOPER NM, HYDE R, KARRAN E, CHRISTIE G, TURNER AJ: A human homolog of angiotensinconverting enzyme. Cloning and functional expression as a captopril insensitive carboxypeptidase. $J$ Biol Chem 275: 33238-33243, 2000.

TRASK AJ, FERRARIO CM: Angiotensin-(1-7): pharmacology and new perspectives in cardiovascular treatments. Cardiovasc Drug Rev 25: 162-174, 2007.

UEHARA Y, MIURA S, YAHIRO E, SAKU K: Non-ACE pathway-induced angiotensin II production. Curr Pharm Des 19: 3054-3059, 2013.

VELEZ JC, RYAN KJ, HARBESON CE, BLAND AM, BUDISAVLJEVIC MN, ARTHUR JM, FITZGIBBON WR, RAYMOND JR, JANECH MG: Angiotensin I is largely converted to Angiotensin (1-7) and Angiotensin (2-10) by isolated rat glomeruli. Hypertension 53: 790-797, 2009.

VICKERS C, HALES P, KAUSHIK V, DICK L, GAVIN J, TANG J, GODBOUT K, PARSONS T, BARONAS E, HSIEH F, ACTON S, PATANE M, NICHOLS A, TUMMINO P: Hydrolysis of biological peptides by human angiotensin-converting enzyme-related carboxypeptidase. J Biol Chem 277: 14838-14843, 2002.

WANG M, TAKAGI G, ASAI K, RESUELLO RG, NATIVIDAD FF, VATNER DE, VATNER SF, LAKATTA EG: Aging increases aortic MMP-2 activity and angiotensin II in nonhuman primates. Hypertension 41: 1308-1316, 2003.

ZHOU X, SHANG D, ZHANG T, LI L, ZHOU T, LU W: Modeling of angiotensin II-angiotensin-(1-7) counterbalance in disease progression in spontaneously hypertensive rats treated with/without perindopril. Pharmacol Res 66: 177-184, 2012.

ZHUO JL, FERRAO FM, ZHENG Y, LI XC: New frontiers in the intrarenal renin-angiotensin system: a critical review of classical and new paradigms. Front Endocrinol (Lausanne) 4: 166, 2013. 